\title{
The Expressive Speech Act Used by Anies Rasyid Baswedan and Recep Tayyip Erdogan as the Reaction of the Attacks in Christchurch New Zealand
}

\author{
${ }^{1}$ Badrut Tamam, ${ }^{2}$ Slamet Setiawan, ${ }^{3}$ Syafi'ul Anam \\ ${ }^{1}$ Language and Literature Education, Postgraduate Program, and LPDP awardee \\ Universitas Negeri Surabaya, Surabaya, Indonesia \\ 2,3 Universitas Negeri Surabaya, Surabaya, Indonesia \\ 1ㅁadruttamamwildan@gmail.com, ${ }^{2}$ slametsetiawan@unesa.ac.id, ${ }^{3}$ syafiul.anam@unesa.ac.id
}

\begin{tabular}{l}
\hline Article Info \\
\hline Article history: \\
Submitted Jan 26, 2020 \\
Revised Feb 21, 2020 \\
Accepted April 26, 2020 \\
Published April 30, 2020 \\
\hline
\end{tabular}

Keywords:

Speech act,

Expressive speech act, Intended meaning, and Personality

\begin{abstract}
This study attempts to compare between Anies Rasyid Baswedan and Recep Tayyip Erdogan in terms of speech act as their reaction of the attacks in Christchurch New Zealand particularly: a) the kinds of expressive speech act used; b) the intended meaning of expressive speech act; and c) the personality differences between them seen the use of speech act. The qualitative method was used to fulfil the three objectives of the study. The data was collected from document that was taken from the utterances used by the two public figures. It was transcribed and then analysed descriptively. The results show that the speakers used three kinds of expressive speech acts, namely: condoling, deploring, and lamenting. Condoling is an expressive speech acts were mostly used to communicate by the speakers. The intended meaning of expressive speech act used by the speakers are determined by interpreting and determining what speakers means in the context. In addition, the personality characters of Anies Rasyid Baswedan are kind, clever, and soft, whereas, the personality characters of Recep Tayyip Erdogan are courageous, influential person, and clever.
\end{abstract}

\section{Corresponding Author:}

\section{Badrut Tamam,}

Student of Language and Literature Education, Postgraduate Program, Universitas Negeri Surabaya.

Jl. Lidah Wetan, Surabaya, Indonesia.

Email: badruttamamwildan@gmail.com

\section{INTRODUCTION}

A few months ago people in the world were shocked by the tragedy of shootings in Christchurch city, New Zealand. At least 49 people were killed and 20 seriously injured in mass shootings at two mosques in Friday, March 15th, 2019 (Sidhu, 2019). The attack was unleashed at lunchtime local time, when the mosques were full of worshippers. Usually, the country is known as a friendly and peaceful state, but a carefully planned and unprecedented atrocity happened in that country. The prime minister of New Zealand mentioned it was a darkest day in New Zealand.

The attacks that were apparently broadcasted on social media get a reaction from some world leaders. The world leaders gave some statements and threats about the tragedy. They were Anies Rasyid Baswedan as governor of DKI Jakarta, and also Recep 
Tayyip Erdogan as president of Turkey. In the statements, they use language that include expressions, or comments as the reaction of the tragedy that is very interesting to be analyzed by using any kind of branches of linguistics theory such as, pragmatics, stylistics, and speech act theory. The world leader statement is very important to analyze because it give strong influences to the audiences or their fans and followers.

Language is a system of sounds, words, sentences, or utterance used by people for delivering idea, thought, and opinion in communication. According to Chomsky (2006), language associates sound and meaning in a particular way to have command of anything in mind, to understand what is said, and to produce a signal with an intended semantic interpretation. One can also say simple that language is an acquired vocal system for communicating meaning based on human life experiences. People use language for many reasons, it could be to express the ideas, feeling, conveying statements, arguments, or for asking information.

Pragmatics is the study of meaning in relation to the speech situation or the usage of language (Leech, 1989). It means that pragmatics field is related to meaning of language when people making conversation among characters. Meaning is formed not from the formal properties of words and constructions, but from the way in which utterances are used and how they relate to the context in which they are produced. Investigating such a kind of relationship is the concern of pragmatics studies. Furthermore, people try to use language to change the world (e.g., by asking another person to do something) or the state of mind or knowledge of others (for instance, by telling them something new). It can be concluded that pragmatics investigates what language users mean, what they do and how they do it in real situations for making communication with others.

In line with the previous theory, pragmatics is the study of how an utterance or speech act; the speaker intends to have meaning when it is used in communication (AlHindawi, 2018). It is depending on the context and situation in which it is used. Austin (1962) defined speech act that it describes what utterances are intended to do such promise, apologize and threaten. It means that speech act is utterance which contain information needed to assist perform and action. It is not only to provide information and facts, but also how these words seemed to carry an action.

Austin (1962) demonstrated that there are three types of acts that can be performed by every utterance, those are; (1) Locutionary acts, (2) Illocutionary acts, and (3) Perlucutionary acts. Locutionary acts mean speaker utters a certain string of words. The purpose of this is just to inform the reader. Illocutionary act are all circumstances being correct, speaker bring about a speech. The Illocutionary acts are analyzed based on context; it is about what is going on behind the text. Context is the background assumed to be shared by speaker and hearer which contribute interpretation of what means by given utterance (Leech, 1989). The last one is perlocutionary acts which mean effects of the speech act on the addressee. In addition, Setyaji (2014:19) argues that perlocutionary acts are the effects of what uttered by speaker, either in the form of real action or just a hope.

Then, dealing with Austin's theory, Al-Hindawi (2018) elaborated the illocutionary acts by dividing it into five types. These include (1) representative, (2) expressive, (3) directive, (4) commissive, and (5) declarative. Illocutionary acts is the function of the 
word, the specific purpose that the speaker have in mind (Cutting, 2002). In addition, the most important study from the three kinds of speech act is illocutionary acts.

The utterances are taken from the statement scripts of prominent figures in the world that execute press conference to deliver expression of condolences. To analyze speech acts, the data were chosen from the utterances conveying by Anies Rasyid Baswedan and Recep Tayyib Erdogan. The two public figures are recently popular in global level, and both of them were delivering speech act as the reaction of the tragedy of mass shootings in the two mosques in New Zealand on the middle of March 2019. In the press conference, there are some utterances describe context and speech act. The utterances are interested to be analysed seen from the context and speech act. One kind of speech act that will be analyzed is expressive speech act.

There are some previous studies which have ever been conducted by other researchers who take issue about speech act. Aguert \& Bernicot (2010) was determining the role of prosody and situational context in children understanding of expressive speech act. The researchers employ experimental design which chose a group of 5- to 9-year-old children and a group of adults that performed a computerized judgment task. They had to determine the speaker's intention on the basis of an utterance produced with a particular prosody (positive or negative) in a particular situational context (positive or negative). The result showed an evidence of a developmental shift in the processing of expressive speech acts: Driven at first by situational context (ages 5 and 7), expressive-interpretation processes start evolving at age 9 , at which point prosody starts to carry as much weight as situational context.

Warsi, Basu, Hirose, \& Fujisaki (2011) conducted a comparative study of prosodic features of utterances of two types of Bangla speech act: the declarative type and the interrogative (yes/no question) whose textual contents are identical in Bangla. The study is based on the analysis of 44 utterances each of the declarative type and the interrogative type spoken by native speakers of Standard Colloquial Bangla (SCB). The finding revealed that declarative speech acts have a gradually falling contour with a terminal fall whereas interrogative utterances have a rising contour and a terminal rise. It is also observed that interrogative utterances have a positive swing larger than that of declarative utterances.

Another study was conducted by Maiz-arevolo (2017). The study used combine approaches, qualitative and quantitative designs. The purpose of the study is to find out whether the students express their emotions when interacting online with their teacher. If so, what expressive speech acts are more frequently used. Similarly, it is to attempt if the use of their mother tongue (Spanish) affects their performance of expressive speech acts in terms of frequency and type. Results showed that students ware frequently performing expressive acts but refrain from expressing their own emotions in an educational setting. Referring to the use of English or Spanish, no significant differences were observed, which appeared that the use of their mother tongue did not seem to affect the kind of acts performed.

Furthermore, Syah, Djatmika, \& Sumarlam (2017) have attempted to find out the types of directive speech act and politeness strategies used in Satu Jam Lebih Dekat talk show on TVOne. The descriptive method with uninvolved conversation observation 
technique was used in the study. The pragmatic theory of Searle's Speech Act and Brown and Levinson's Politeness Strategy are used as the main theory in the study. As the results, the study revealed that the types of directive speech act used in Satu Jam Lebih Dekat program are to request, to order, to please, to invite, to ask, to forbid, to convince, to show, to obligate, to hope, to want, to warn, and to advise. Additionally, the politeness strategies are bald on record, positive politeness, negative politeness, and off record. The politeness of directive speech acts supports the effectiveness of talk show because of some factors such as types of directive speech act and politeness strategy.

The previous studies have different focus in analysing the speech act. Even though there is a similarity in taking issue of expressive utterances, none of the studies which analyzed the expressive speech act used by the famous world leader in the shootings tragedy in New Zealand. Thus, this study focuses on the use of speech act produced by Anies Rasyid Baswedan and Recep Tayyip Erdogan as the reaction of the Attacks in Christchurch New Zealand. The questions are: 1) What are the kinds of expressive speech act used? 2) What are the intended meanings of expressive speech act? 3) What are the personality differences between them based on the expressive speech act used?

\section{THEORY AND METHODS}

\section{Speech Acts}

The first concept of speech acts was introduced by the British philosopher J. L. Austin, (1962), that is one of the ingredients of pragmatics (Sakulpimolrat, 2019). Austin (1962) developed the first systematic theory of utterances as human actions. Followed by Grundy (2000: 53) as cited in (Al-Hindawi, 2018), a speech act is "the act or the intent that a speaker accomplishes when using language in context, the meaning of which is inferred by hearers". Actually, speech act is a branch of linguistics that studies language from the aspect of actual usage (Syah et al., 2017). Additionally, actions that are performed through utterances are generally called speech act (Fitriana, 2013: 15). Therefore, it can be argued that speech act theory concerns the language user's intention to attain certain communicative goals by performing acts through the use of language.

According to Searle (1969) as cited in Al-hindawi (2018), speech act was distinguished into five major classes, those include:

\section{Representative (Assertive)}

It is act that has "truth-values which state what the speaker believes to be the case or not". The speaker believes what he says is true. The speaker knows by observation, experience, or knowledge. It is used assert, conclude, state, report, etc. For example:
a. The sun rises in the east.
b. The earth is flat.
c. Ronaldo is the best football player. 


\section{Expressive}

It is act that reveals the speaker's feelings and attitudes. They indicate the psychological state of the speaker in statements of pleasure, pain, dislike, joy, or sorrow. Expressive describes speakers' expression of happiness, sadness, etc. For example:
a. I am proud of you.
b. Happy Ied Mubarok.
c. I am sorry to hear that.

\section{Directive}

It is essentially positive or negative commands to express the speaker's wants. They include: command, order, request, suggest, advice, and so forth. In using a directive, the speaker attempts to get the hearer to do something. For example:
a. Close the door, please!
b. You should see the doctor.
c. Keep your chin up!

\section{Commissive}

It is kind of speech act in which the speakers use it to commit himself to some future actions. It express what the speakers intend. The speakers express an utterance to commit something. Commisive is used in promising, threatening, offering, vowing, and swearing. These are the example of the Commisives.
a. I will always love you.
b. I will wait for you.
c. I will always come on time

Commissive is common in the discourse of characters in fiction, but rare in the narrator's discourse, though the beginnings of some novels function as a commissive.

\section{Declaration}

It is kinds of speech act that change the world by the utterances, such as baptizing, declaring, resigning, dismissing, etc. Declaration is performed appropriately if the speaker has a specific institutional role in a special context. The successful performance of declarations depends on the status of the speaker and the precise circumstances surrounding the event. For example:

a. You five years "imprisonment"

\section{Expressive speech act}

Expressive is one type of speech acts in which the speakers express their feeling (Nurhidayah, 2013:68). This type of speech acts often occurs in the conversation between one person to another. Expressive speech acts is expressions which based on 
psychological state and relate to the expression of speaker's feeling upon the hearer. According to Norrick theory (1978) and Ronan \& Lausanne study (2015), there are nine different kinds of expressive illocutionary acts. These are:

1. Apologizing, where an agent-speakers express negative feelings towards a patientaddressee to appease them;

2. Thanking, where the speakers express positive feelings to the addressee, who has done a service to the speakers;

3. Congratulating, where the speakers have observed that the addressee has either benefitted from or carried out a positively valued event;

4. Condoling, which resembles congratulating, except that the experienced event is negatively valued;

5. Deploring, or censoring, in which the addressee is criticised for an event which had a negative impact on the speaker or a third person;

6. Lamenting, where the speaker expresses his or her own misfortune, either at their own or somebody else's doing, the speaker is also the main observer;

7. Welcoming, where the speaker expresses positive feelings towards the arrival of the addressee;

8. Forgiving, which is found to have a similar conceptual set-up as deploring, except for the fact that the speaker does not resent the addressee's action; and

9. Boasting, where the speaker expresses positive feelings about his or her own actions towards and addressee.

\section{Intended meaning}

According to Brown (1983), intended is words, phrase and sentence appeared in a textual record of a discourse are the evidence of a producer's or writer attempts to convey message to his interlocutor or hearer. Hence, the hearers interpret the intended meaning of speaker utterance. In addition, Brown (1983) stated that we have isolated three aspects of the process in interpreting a speaker or writer's intended meaning in producing discourse. These involve in computing the communication, the communicative function (how to make the message), using general socio-cultural knowledge (facts about the world) and determining the inference to be made.

As what has been cited above, this study uses one aspect of process interpreting a speaker or writer intended meaning in producing utterance. The aspect is determining the inference to be made. Brown (1983) stated that inference is also used to describe the process with the reader or hearer must go through to get the literal meaning of what is written or said to what the writer or speaker intended to convey. Furthermore, inference is interpretation what they read or hear. In addition, inference, inference is a prediction or deduction about something in written text often to do with what the character may see, hear, smell, taste, or feel. 


\section{Personality theory}

According to Feist (2008) personality is a pattern of relatively permanent trait and unique characteristic that give both consistency and individual of a person's behaviour over time, and stability of behaviour across the situation. Trait is unique; it is possessed by each people but different patterns for each individual, Hence, each person has a unique personality. Additionally, character is unique quality of a person that includes such attributes as temperament, physique, and intelligence.

The similar perspective comes from Ryckman (2007). Personality is defined as the dynamic and organized set of characteristics possessed by an individual that uniquely influences his or her cognitions, motivations, and behaviours in various situations. The study of personality as primarily the scientific analysis of individual differences helps to account for why and how people react uniquely, and often creatively, to various environmental or situational demands.

\section{Method}

Referring to the research questions in the previous section, this research employs qualitative research design. The qualitative type is regarded to be the most appropriate design to be used in this research as the data are in form of words, sentences, and picture. McMillan (2008) states the focus of qualitative study is to know the meaning through verbal description and observation rather than through numbers. Similarly, Creswell (2014) adds that qualitative research tends to use words or pictures rather than statistics to describe the central phenomenon under the research. Therefore, this research type is employed to describe how expressive speech act and intended meaning used by Anies Rasyid Baswedan and Recep Tayyip Erdogan in the press conference.

The source of date used is the speech transcripts from the Anies Rasyid Baswedan and Recep Tayyip Erdogan statement in the press conference. In the process of collecting data, here are some steps which are done: selecting the video conference; watching the video conference; understanding the contents; recording the speech into transcript; and identifying the speech act. On the next level, the theory of speech act by is used to analyse the data. The steps are as follows: collecting data of the speech of Anies Rasyid Baswedan and Recep Tayyip Erdogan from You Tube; selecting the expressive speech act used; and describing how expressive speech act used by the two speakers; and describing the intended meaning of the speakers' utterances.

\section{FINDINGS AND DISCUSSION}

In order to answer the questions, this section presents the analysis finding based on theory applied. Beforehand, let study the following speech transcripts delivered by Anis Rasyid Baswedan and Recep Tayyip Erdogan that had been taken from the YouTube channel. 


\begin{abstract}
Anies Rasyid Baswedan's Speech
Inna lillahi wainna ilaihi rojiun. Harrowing news from Christchurch came out earlier this afternoon. Jakarta was shocked, more than 40 people have been killed in an unthinkable act of terror, in a shooting during Juma'ah prayer. On behalf of the people of Jakarta, we are extending our deepest condolences to the families of those whose live had been taken away, and also to the Muslim community in New Zealand. We pray to Allah all victims will be granted syuhada, will be granted jannah. Jakarta stands in solidarity with Christchurch, with New Zealand, and its people who is known for their peacefulness, openness, and warm toward other people from all work of life. We believe the government of New Zealand will take this matter extremely serious, and justice will be served. Thank you, May the blessing of Allah be upon us all.
\end{abstract}

\title{
Recep Tayyip Erdogan's Speech
}

I vehemently condemn the attack targeting Muslims in New Zealand who came together for Friday prayer. With this attack the rise of islamophobia, which has been watched, and even encouraged by the world for long time, crossed the line of personal assaults and reached the level of massacre. Moreover, there is an actual terrorist, a killer out there who even divides my country as Anatolia and western part. Unless immediate action is taken, it is inevitable to see new catastrophic news which are the results of this deterioration. We invite the whole world especially western nations to take immediate measures against this movement that threatens the entire humanity.

\section{Kinds and Intended meaning of expressive speech act used by the characters}

Expressive speech acts covers many kinds such as apologizing, thanking, condoling, deploring, congratulating, etc. The expressive speech acts performed by the characters in the press conference are condoling, deploring, and lamenting. Then, how the expressive acts exploited by them are described and analyzed here. The following is the description of kind expressive speech act and intended meaning which are produced by the characters. Norrick's (1978) and Ronan \& Lausanne's (2015) framework were being implemented in this session.

\section{Speech used by Anies Rasyid Baswedan}

\section{a. Condoling}

The term of condoling means that the character expresses his feeling of having sympathy and sadness for the family or close friend of the victims. The data belong to condoling employed by Anies Rasyid Baswedan in the press conference are explained below:

(1) On behalf of the people of Jakarta, we are extending our deepest condolences to the families of those whose live had been taken away.

(2) Jakarta stands in solidarity with Christchurch 
From the utterances above, it is found the condoling as kind of expressive speech act. It can be seen by the utterances of Anies Rasyid Baswedan. "......We are extending our deepest condolences to the families......" in the utterance number (1), it is clear that this utterance has expressive meaning. By express this, Anies Baswedan gives condoling to families of victims. In addition, by saying "Jakarta stands in solidarity with Christchurch" an in the utterance number (2), Anies Basweedan was showing the sadness and solidarity with Christchurch people.

\section{b. Deploring}

The term deploring means that the character has intention to say or think that someone did something wrong. It usually occurs in a situation in which people declare someone or something for a fault or wrong doing. The message of deploring is conveyed directly to the hearer. The data belong to deploring speech act employed by Anies Rasyid Basweda in the press conference are explained below:

(1) Jakarta was shocked, more than 40 people have been killed in an unthinkable act of terror, in a shooting during juma'ah prayer

(2) We believe the government of New Zealand will take this matter extremely serious, and justice will be served

Anies Baswedan deplores the tragedy in New Zealand that causes more than 40 people killed. People in Jakarta are also shocked because of the attacks. He also asks the government of New Zealand to give a serious action, and the justice should be served.

\section{c. Lamenting}

The term Lamenting indicates that the character wants to express sadness and feeling sorry about something. Referring to that condition, the character wants to exprees his sadness about the tragedy happens in the New Zealand, continued by giving prayer to all victims. The data belong to lamenting speech act employed by Anies Rasyid Basweda in the press conference are explained below:

(1) We pray to Allah all victims will be granted syuhada, will be granted jannah.

(2) .......... New Zealand people is known for their peacefulness, openness, and warm toward other people from all work of life.

Anies Baswedan is also lamenting the tragedy. He represents the Indonesian people especially Jakarta people to support and pray, may Allah grants all the victims with syuhada and jannah. In addition, he laments the shootings tragedy in New Zealand that usually New Zealand people is known for their peacefulness, openness, and warm to all people. 


\section{Speech used by Recep Tayyip Erdogan}

\section{a. Condoling}

The data belong to condoling employed by Recep Tayyip Erdogan in the press conference are explained below:

(1) I vehemently condemn the attack targeting muslims in New Zealand who came together for Friday prayer

From the expression used by Erdogan, he shows that he gives the condolences to the tragedy in New Zealand. He also condemns the agents or the actors of the attack that targeting muslim Friday prayer.

\section{b. Deploring}

The data belong to deploring employed by Recep Tayyip Erdogan in the press conference are explained below:

(1) With this attack the rise of islamophobia, which has been watched, and even encouraged by the world for long time, crossed the line of personal assaults and reached the level of massacre.

(2) Moreover there is an actual terrorist, a killer out there

(3) We invite the whole world especially western nations to take immediate measures against this movement that threatens the entire humanity.

Erdogan deplores the tragedy. Initially, the western people claims and encourages the term islamophobia, but in the tragedy the victims are the Muslim people. Erdogan mentions the agent of the attacks is the actual terrorist that crosses the line of personal assaults and reaches the level of massacre. In addition, Erdogan asks the people in the world especially to the world leaders in western to take the immediate measure to against the movement.

Based on the finding above, it is found that each utterance has different intention based on context and hearer's interpretation. Anies Baswedan and Recep Tayyip Erdogan convey their utterance and the hearers interpret the intended meaning of it. Not all of their utterance has intended meaning. Some of their utterances are visible meaning without interpreting it. In addition, the kinds of expressive speech act used by the characters are condoling, deploring, and lamenting. In contrast, Recep Tayyip Erdogan did not use the lamenting of expressive speech act. Majority of his utterances are deploring.

\section{The intended meaning of expressive speech act used by Anies Rasyid Baswedan and Recep Tayyip Erdogan related to their personality}

In this part the analysis of Anies Baswedan and Recep Tayyip Erdogan personality as the object character in this research is provided. The Feist's (2008) and Ryckman's (2007) 
framework were used to examine the personality character of the speakers through their utterances.

Anies Baswedan is described as young man that success to be leader as governor in DKI Jakarta, Indonesia. His great career begins from the position as rector in Paramadina University. He has inaugurated as youngest rector in Indonesia in the age of 38. Then, he has been as minister of education and culture in Indonesia. The last position is as governor in Jakarta, Indonesia. Besides, Recep Tayyip Erdogan is famous Turkish politician who served as prime minister in 2003 until 2014 and president of Turkey in 2014 until now.

The personal character of Anies Baswedan based on the utterances that is used in the expressive acts can be categorized into:

a. kind

Kind value that Anies has in the statements is reflected by his humanity to the mass shootings tragedy in the two masques in New Zealand. He delivers condolences to families of the victims. He also prays to Allah, all victims granted syuhada, and jannah.

b. clever

Anies' expression in delivering condolences is grammatically ordered. His fluently in producing a statement is indicated that he is an educated person, or clever person.

c. soft

From the style of language, and grammatical structure used by Anis, it indicates as a soft, calm, and friendly person. He seldom used high intonation, and condemnation words in conveying a statement.

In the other hand, the personal character of Recep Tayyip Erdogan based on the utterances that is used in the expressive acts can be categorized into:

a. courageous

A courageous value is showed by Erdogan in the statement that he vehemently condemns the attack targeting muslims in New Zealand who came together for Friday prayer. He is really angry with the mass shooting tragedy in New Zealand.

b. influential person

This value is reflected by Erdogan in the statement that he invites the world leaders especially western leaders to against the terrorism movement. He asks the whole world nations to take immediate measures against the movement that threatens the entire humanity.

c. clever

This value is known from the Erdogan speech in giving reaction to the terrorism movement in New Zealand. He chooses an appropriate diction, and language style in conveying the statement. 
Based on the findings of the kinds of expressive speech act, it can be seen that there are three kinds of expressive speech acts. They are condoling, deploring, and lamenting. It means that the main character does not use all kinds of expressive speech act. Condoling is an expressive speech acts mostly used to communicate by the speakers. However, the lamenting could not be found in Erdogan utterances. He mostly used deploring expressive speech act.

It is found several intended meaning of Anies Baswedan and Recep Tayyip Erdogan sentences based on inference to be made and context. The finding is fit to what (Brown, 1983) has isolated it into three aspect of the process in interpreting a speaker or writer's intended meaning in producing discourse. These involve in computing the communication the communicative function (facts about the world) and determining the inference to be made. Further, this research is a little bit different with the theory above. In this research only use two aspects in interpreting the speaker meaning namely inference to be made and context use.

Related to the last question of this study, it is about the intended meaning of expressive speech acts of Anies Baswedan and Recep Tayyip Erdogan which is related to their personality as the speakers in the live conference. Implementing Feist's (2008) and Ryckman's (2007) framework, it could be revealed that Anies Baswedan personality is kind, clever, and soft. Besides, the personality of Recep Tayyip Erdogan is courageous, influential person, and clever. The different Personal character of Anies Baswedan and Recep Tayyip Erdogan are influenced by some factors such as: culture, language, social, family, and emotional determinant.

\section{CONCLUSION}

Having done the analysis and discussion, it comes to the conclusion that both speakers produce utterances that contain the expressive speech acts. They are condoling, deploring, and lamenting even though the use of them is in different levels. The condoling of the expressive speech act category reaches the highest frequency; and it is followed by deploring; and the lowest frequency is lamenting. When it comes to the function, some speech acts lead to invite the hearer to do something, to commit the speaker's future action, and to express speaker's feeling. These functions are inferred from what the two speakers said during giving comments. From their speech acts produced, even though not precisely accurate, the quality of the two speakers might be predicted. Anies Baswedan is kind, clever, and soft, whereas Recep Tayyip Erdogan is courageous, influential, and clever.

This study focuses only kinds and function based Norrick theory (1978) that is followed by Ronan \& Lausanne study (2015). Further study can be conducted by employing another theory, take for an example, Searle (1976) from aspects of speech acts, such as declarative, and commissive, and so on. 


\section{REFERENCES}

Aguert, M., Laval, V., Le Bigot, L., \& Bernicot, J. (2010). Understanding expressive speech acts: the role of prosody and situational context in French-speaking 5- to 9-year-olds. Journal of Speech Language and Hearing Research, 53(6), 1629-1642.

Al-Hindawi, P. F. H. (2018). Pragmastylistics : the integration of pragmatics and stylistics. University of Babylon: College of Education for Human Sciences, 101(24), 113-132.

Austin, J. L. (1962). How to do things. Cambridge, UK: Harvard University Press.

Brown, G. Y. (1983). Discourse analysis. Cambridge, UK: Cambridge University Press.

Chomsky, N. (2006). Language and mind third edition. New York: Cambridge University Press.

Creswell, W. J. (2014). Research design: qualitative, quantitative, and mixed methods approach 4 edition. London: SAGE Publications.

Cutting, J. (2002). Pragmatics and discourse. London: Routledge.

Feist;, J., \& Feist, G. J. (2008). Theories of personaliy 6th. New York: McGraw Hill Company.

Fitriana, I. (2013). Translation Analysis of directive speech acts in eat play love and its translation into Indonesian. Prasasti: Journal of Linguistics, 2(2), 13-28.

Leech, G. (1989). Principles of pragmatics. London: Longman.

Maiz-arevolo, C. (2017). Expressive speech acts in educational e-chats. Pragmática Sociocultural / Sociocultural Pragmatics, 5(2). https://doi.org/10.1515/soprag-20170016

McMillan, J. H. (2008). Educational research fundamentals for the consumer fifth edition (5th ed.). NewYork: HarperCollins CollegePublishers.

Norrick, N. R. (1978). Expressive illocutionary acts. Journal of Pragmatics, 2(3), 277-291. https://doi.org/10.1016/0378-2166(78)90005-x

Nurhidayah, V. A. (2013). An analysis of translation techniques and quality in terms of accuracy, acceptability and readability of PI's Expressive Speech Act in the Film of PI. PRASASTI: Journal of Linguistics, 02 (02), 67-79.

Ronan, P., \& Lausanne, U. De. (2015). Categorizing expressive speech acts in the pragmatically annotated SPICE Ireland corpus. ICAME Journal, 39, 282-290. https://doi.org/10.1515/icame-2015-0002

Ryckman, R. M. (2007). Theories of Personality. United States of America: Michele Sordi.

Sakulpimolrat, S. (2019). The Analysis of Translation Techniques and Translation Quality of Directives Speech Act in The Little Prince Novel. PRASASTI: Journal of Linguistics, $4(2), 166-179$.

Searle, J. R. (1976). A classification of illocutionary acts. Language in Society, 5(1), 1-23.

Setyaji, A. (2014). How Speech Acts Work in Translation: An Analysis on Speech Acts in Translating a Script of Titanic Film. PRASASTI: Journal of Linguistics, 03(01), 14-31.

Sidhu, H. R. S. (2019). 49 killed in mass shooting at two mosques in Christchurch , New Zealand. CNN News, pp. 1-6.

Syah, N. A., Djatmika, \& Sumarlam. (2017). The Politeness of directive speech acts in Satu Jam Lebih Dekat on Tv One (Pragmatic Approach). PRASASTI: Journal of Linguistics, 2(2), 300-315. 
Warsi, A. H., Basu, T., Hirose, K., \& Fujisaki, H. (2011). Prosodic comparison of declarative and interrogative utterances in standard colloquial Bangla. IEEE 2011 International Conference on Speech Database and Assessments (Oriental COCOSDA), 56-61. 